\title{
Lymphoepithelial carcinoma of the salivary gland: in situ detection of Epstein-Barr virus
}

\author{
S Y Leung, L P Chung, S T Yuen, C M Ho, M P Wong, S Y Chan
}

\begin{abstract}
Aim-To examine the role of Epstein-Barr virus (EBV) in lymphoepithelial carcinoma of the salivary gland in Hong Kong Chinese.

Methods-Ten cases of lymphoepithelial carcinoma of the salivary gland (eight parotid and two submandibular) were examined. In situ hybridisation was used to localise EBER RNA, immunohistochemical methods to detect expression of latent membrane protein 1 (LMP-1) in EBV positive tumours, and Southern blot analysis to examine the clonality of EBV in the two cases where frozen tissue was available.

Results-None of the cases had a history of Sjögren's syndrome or histological evidence of a benign lymphoepithelial lesion. The IgA antibody titre against EBV viral capsid antigen was elevated in four cases. All cases were EBV positive by in situ hybridisation, with a strong uniform positive signal in the epithelial cells, and all cases expressed LMP-1. Southern blot analysis revealed that the clonal episomal form of the virus was present. Two of the three female patients in this series also developed carcinoma of cervix. One of these carcinomas had histological features of a lymphoepithelioma-like carcinoma but was EBV negative.

Conclusions-A consistent association between EBV and lymphoepithelial carcinoma of the salivary gland was found. The presence of the virus in a clonal episomal form, and the expression of LMP-1 viral oncoprotein is further evidence of the role of EBV in the oncogenesis of this tumour.
\end{abstract}

(f Clin Pathol 1995;48:1022-1027)

\author{
Department of \\ Pathology, \\ The University of \\ Hong Kong, \\ Queen Mary Hospital \\ Compound, Hong \\ Kong \\ $S$ Y Leung \\ L P Chung \\ $S$ T Yuen \\ M P Wong \\ S Y Chan \\ Department of \\ Surgery \\ $\mathrm{C} M \mathrm{Ho}$ \\ Correspondence to: \\ Dr S Y Leung. \\ Accepted for publication \\ 24 April 1995
}

Keywords: Epstein-Barr virus, lymphoepithelial carcinoma, salivary gland.

Epstein-Barr virus (EBV) has been demonstrated in carcinomas of various organs, including the nasopharynx,$^{1-4}$ salivary gland, ${ }^{5-7}$ lung, ${ }^{89}$ thymus, ${ }^{10}$ and stomach. ${ }^{112}$ Most of these EBV associated tumours have characteristic histological features, such as syncytial sheets of undifferentiated malignant cells in a dense lymphoid infiltrate. Tumours with this basic histological pattern were commonly referred to as lymphoepitheliomas. In the salivary gland the terms lymphoepithelial carcinoma, malignant lymphoepithelial lesion or undifferentiated carcinoma with lymphoid stroma are used preferentially. Tumours with similar morphological appearances arising from organs other than the nasopharynx and salivary gland are commonly termed lymphoepitheliomalike carcinomas. Recently, EBV has also been demonstrated in a minority of conventional gastric adenocarcinomas. ${ }^{1314}$ There seems to be a strong ethnic variation in the extent of EBV involvement in lymphoepitheliomas of different organs. For instance, EBV is found in most lymphoepitheliomas of the nasopharynx irrespective of the ethnic group, ${ }^{134}$ but for lymphoepithelial carcinoma of the salivary gland, the association is less consistent. Eskimos in Greenland have a high incidence of lymphoepitheliomas in both the salivary gland and nasopharynx $x^{15-18}$ and familial clustering of these two tumours is commonly observed. ${ }^{1517}$ An association between this group of tumours and EBV was suggested by serological and nucleic acid hybridisation studies. ${ }^{5-719}$ A recent in situ hybridisation study demonstrated the presence of the virus in all lymphoepithelial carcinomas of the salivary gland in Eskimos ${ }^{6}$ but the lymphoepithelial carcinomas of the two white patients in that series were EBV negative. In another series lymphoepithelial carcinomas of the salivary gland from four white patients were also EBV negative. ${ }^{20}$

The Chinese have a high incidence of lymphoepithelioma of the nasopharynx, but in contrast to Eskimos, lymphoepithelial carcinoma of the salivary gland is uncommon. A previous study on Hong Kong Chinese with lymphoepithelial carcinoma of the salivary gland suggested that EBV was present given the high prevalence of elevated serum IgA titres against the EBV capsid antigen. ${ }^{19} \mathrm{~A}$ single case report on a Chinese patient also reported the presence of EBV on Southern blotting and immunohistochemistry. ${ }^{7}$ Here, we report an association between EBV and lymphoepithelial carcinoma of the salivary gland in Hong Kong Chinese.

\section{Methods}

Ten Hong Kong Chinese patients (seven men and three women aged from 31 to 72 years (median 41.5 years)) with lymphoepithelial carcinoma of the salivary gland were included in the study. Clinical data were retrieved from the hospital records. The cases were reviewed and representative paraffin wax blocks from the tumour and surrounding non-neoplastic glands were retrieved. A lymphoepithelioma-like carcinoma arising from the uterine cervix in one of the patients (case 4) was also included. A DNA fragment containing EBER-1 and EBER2 (EBV nucleotides 6661-7119) was prepared using the polymerase chain reaction and cloned 
into the Bluescript vector, from which antisense RNA probes were generated by in vitro transcription. In situ nucleic acid hybridisation was performed as described previously. ${ }^{914} \mathrm{Di}$ goxigenin and/or ${ }^{35} \mathrm{~S}$ labelled probes were used. Two cases of nasopharyngeal carcinoma known to be positive for EBV were used as positive controls. All EBV negative cases were probed for $\kappa$ and $\lambda$ light chains to confirm the integrity of the RNA. ${ }^{14}$

Fresh tumour tissue from case 8 and the cervical lymph node metastases from case 7 were snap frozen in liquid nitrogen and stored at $-70^{\circ} \mathrm{C}$. High molecular weight DNA was extracted from the frozen blocks, digested with $B a m \mathrm{H} 1$, separated on a $0.8 \%$ agarose gel, and transferred onto a Hybond-N membrane. The cell line B95-8, harbouring the lytic form of EBV, was used as a positive control. Hybridisation studies, using a XhoI fragment of the terminal repeat region of EBV genome as a probe for clonal analysis, were performed. ${ }^{21}$ The hybridisation conditions were as previously described. ${ }^{9}$ For immunohistochemical staining, a cocktail of monoclonal antibodies against the EBV latent membrane protein (LMP-1) (CS $1-4$, diluted 1 in 50; Dako, Glostrup, Denmark) was used on paraffin wax sections prepared from all of the EBV positive cases. Standard immunohistochemical methods incorporating Streptavidin-biotin peroxidase were applied. The slides were pretreated in a microwave oven $\left(95^{\circ} \mathrm{C}\right.$ for nine minutes in citrate buffer ( $\mathrm{pH} \mathrm{6.0))} \mathrm{to} \mathrm{facilitate} \mathrm{antigen}$ retrieval. Cell blocks prepared from Raji and B95-8 cell lines, harbouring 50 copies and the lytic form of EBV, respectively, were used as positive controls. A case of middle ear squamous cell carcinoma, known to be EBV negative, was used as negative control. For all the cases, negative controls were also obtained by replacing the primary antibody by Tris buffered saline.

\section{Results}

CLINICAL FINDINGS

The clinical details of the 10 patients are presented in the table. Eight of the tumours were located in the parotid gland and two in the submandibular gland. There was no history of
Sjögren's syndrome and the possibility of a metastasis from a primary nasopharyngeal carcinoma was excluded by direct examination and biopsy of the nasopharynx. Four patients had elevated serum IgA levels against EBV capsid antigen. The follow up period ranged from two to 163 months and most patients were alive and well at the end of the follow up period, except for one who died of liver metastasis nine months after surgery. Case 3 developed a solitary lung metastasis 31 months after surgery. A wedge resection of the lung lesion was performed, and he is currently alive with no residual disease 31 months after the second operation. Case 4 developed a local recurrence one, five and nine years after the initial surgery; the first two recurrences were successfully treated by radiotherapy alone; a surgical resection was performed for the third recurrence. The patient is alive with no residual disease more than four years after the last surgery. This patient also developed a lymphoepithelioma-like carcinoma of the uterine cervix one year before her third recurrence; the tumour was successfully treated by radiotherapy and Wertheim hysterectomy. Case 9 also had a history of carcinoma of the uterine cervix treated by radiotherapy before development of the salivary gland lymphoepithelial carcinoma. Unfortunately, the pathological material was not available for review in that case.

\section{PATHOLOGY}

The 10 lymphoepithelial carcinomas had similar morphology with a recurrent pattern of islands of primitive malignant epithelial cells surrounded by dense lymphoid infiltrate, giving a low power appearance of a jigsaw puzzle pattern. In some areas the tumour cells were spindle shaped, giving rise to a fascicular growth pattern in a desmoplastic stroma. The cytoplasmic borders were usually indistinct, resulting in a syncytial appearance. The nuclei were oval and vesicular with one or several distinct nucleoli (fig 1A). Permeation of lymphoid cells into the epithelial islands was prominent and follicles with germinal centres were frequently seen in the surrounding stroma. Definite squamous differentiation was not seen.

Clinical features of the 10 patients with lymphoepithelial carcinoma of the salivary gland

\begin{tabular}{|c|c|c|c|c|c|c|c|}
\hline $\begin{array}{l}\text { Case } \\
\text { no. }\end{array}$ & $\begin{array}{l}\text { Sex/age } \\
\text { (years) }\end{array}$ & Site & $\begin{array}{l}\text { TNM } \\
\text { Staging } \ddagger\end{array}$ & Treatment & Recurrence & $\begin{array}{l}\text { Treatment of } \\
\text { recurrence }\end{array}$ & Outcome \\
\hline $\begin{array}{l}1 \\
2\end{array}$ & $\begin{array}{l}\mathrm{F} / 57 \\
\mathrm{M} / 41^{*}\end{array}$ & $\begin{array}{l}\text { Parotid gland } \\
\text { Submandibular } \\
\text { gland }\end{array}$ & $\begin{array}{l}\text { T4N2bM0 } \\
\text { T2NOM0 }\end{array}$ & $\begin{array}{l}\text { Radical parotidectomy + RND + RT } \\
\text { Submandibulectomy }+\mathrm{RT}\end{array}$ & $\begin{array}{l}\text { Liver } \\
\text { None }\end{array}$ & $\begin{array}{l}\text { None } \\
\text { None }\end{array}$ & $\begin{array}{l}\text { DOD, } 9 \mathrm{~m} \\
\text { AW, } 63 \mathrm{~m}\end{array}$ \\
\hline $\begin{array}{l}3 \\
4\end{array}$ & $\begin{array}{l}\mathrm{M} / 42 \\
\mathrm{~F} / 36+\end{array}$ & $\begin{array}{l}\text { Parotid gland } \\
\text { Parotid gland }\end{array}$ & $\begin{array}{l}\text { T2NOMO } \\
\text { TINOMO }\end{array}$ & $\begin{array}{l}\text { Total conservative parotidectomy }+\mathrm{RT} \\
\text { Superficial parotidectomy }+\mathrm{RT}\end{array}$ & $\begin{array}{l}\text { Lung }(31 \mathrm{~m} \text { postop) } \\
\text { Local }(12,60,108 \mathrm{~m} \\
\text { postop) }\end{array}$ & $\begin{array}{l}\text { Wedge resection } \\
\text { RT for } 1 \text { st and 2nd } \\
\text { recurrence; resection for } \\
\text { 3rd recurrence }\end{array}$ & $\begin{array}{l}\mathrm{AW}, 62 \mathrm{~m} \\
\mathrm{AW}, 163 \mathrm{~m}\end{array}$ \\
\hline $\begin{array}{l}5 \\
6 \\
7\end{array}$ & $\begin{array}{l}M / 31^{*} \\
M / 36 \\
M / 32^{*}\end{array}$ & $\begin{array}{l}\text { Parotid gland } \\
\text { Parotid gland } \\
\text { Submandibular } \\
\text { gland }\end{array}$ & $\begin{array}{l}\text { T1N0M0 } \\
\text { T2N0M0 } \\
\text { T2N1M0 }\end{array}$ & $\begin{array}{l}\text { Superficial parotidectomy }+\mathrm{RT} \\
\text { Total conservative parotidectomy }+\mathrm{RT} \\
\text { Submandibulectomy + excision of } \mathrm{LN}+\mathrm{RT}\end{array}$ & $\begin{array}{l}\text { None } \\
\text { None } \\
\text { None }\end{array}$ & $\begin{array}{l}\text { None } \\
\text { None } \\
\text { None }\end{array}$ & $\begin{array}{l}\text { AW, } 38 \mathrm{~m} \\
\text { AW, } 10 \mathrm{~m} \\
\mathrm{AW}, 3 \mathrm{~m}\end{array}$ \\
\hline $\begin{array}{r}8 \\
9 \\
10\end{array}$ & $\begin{array}{l}\text { M/45* } \\
\mathbf{F} / 72+ \\
\mathbf{M} / 66\end{array}$ & $\begin{array}{l}\text { Parotid gland } \\
\text { Parotid gland } \\
\text { Parotid gland }\end{array}$ & $\begin{array}{l}\text { T3N1M0 } \\
\text { NA } \\
\text { NA }\end{array}$ & $\begin{array}{l}\text { Radical parotidectomy + excision of } \mathrm{LN}+\mathrm{RT} \\
\text { NA } \\
\text { NA }\end{array}$ & $\begin{array}{l}\text { None } \\
\text { NA } \\
\text { NA }\end{array}$ & $\begin{array}{l}\text { None } \\
\text { NA } \\
\text { NA }\end{array}$ & $\begin{array}{l}\text { AW, } 2 \mathrm{~m} \\
\text { NA } \\
\text { NA }\end{array}$ \\
\hline
\end{tabular}

$\mathrm{RND}=$ radical neck dissection; $\mathrm{RT}=$ radiotherapy; $\mathrm{LN}=$ lymph node; $\mathrm{AW}=$ alive and well; $\mathrm{DOD}=$ died of disease, Postop = postoperative; $\mathrm{m}=\mathrm{months} ; \mathrm{NA}=\mathrm{no}$ available.

* These patients had elevated IgA antibody titres to EBV capsid antigen.

† These patients also had cervical carcinoma.

+ AJCC $1988{ }^{22}$ 


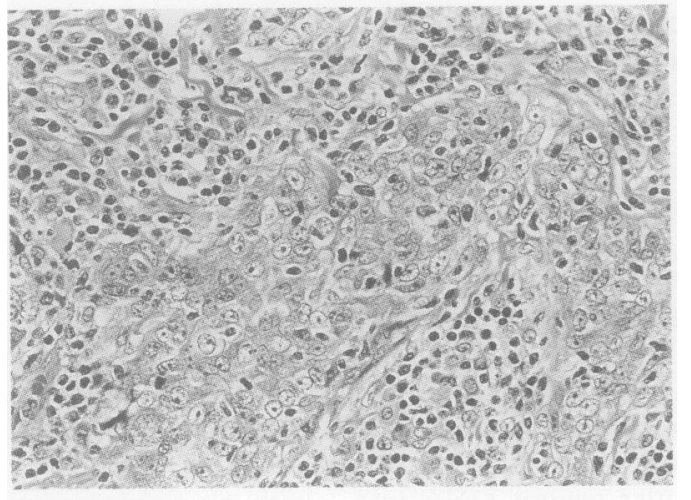

(A)

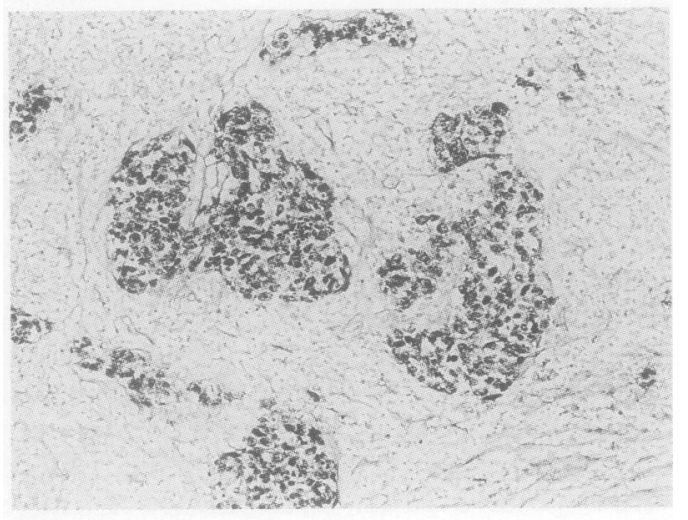

(B)

Figure 1 (A) Lymphoepithelial carcinoma of the parotid gland (case 2). Syncytial clusters of malignant cells surrounded by dense lymphoid infiltrate are evident. The nuclei are vesicular with central prominent nucleoli. (Haematoxylin and eosin, original magnification $\times 300$.) (B) In situ hybridisation using a digoxigenin labelled EBER probe. The nuclei of the malignant epithelial cells are strongly positive (original magnification $\times 120$ ).

The inflammatory infiltrate was confined to a narrow zone around the tumour, outside of which the salivary gland tissue was normal. There were no benign lymphoepithelial lesions.

The carcinoma of the uterine cervix in case 4 was composed of syncytial sheets of poorly differentiated malignant cells associated with an intense lymphocytic and plasma cell infiltrate in the stroma. In some areas permeation of the epithelial island by lymphocytes added further to the typical picture of a lymphoepithelioma (fig 2A). The malignant cells had scanty pale cytoplasm and elongated dark nuclei with small nucleoli. Glandular formations were detected in some areas, with cytoplasmic mucin production in the glands. The morphology of this cervical carcinoma was similar to the EBV associated poorly differentiated adenocarcinoma with an intense lymphoid infiltrate in the stomach-that is, lymphoepithelioma-like carcinoma of the stomach.

\section{IN SITU HYBRIDISATION}

EBV EBER RNA was strongly expressed in the malignant epithelial cells in all the 10 lymphoepithelial carcinomas of the parotid and submandibular glands (fig 1B) while scattered EBV positive reactive lymphoid cells were noted in three cases (fig 3). All normal salivary glandular epithelium was negative. The lymphoepithelioma-like carcinoma of the uter-

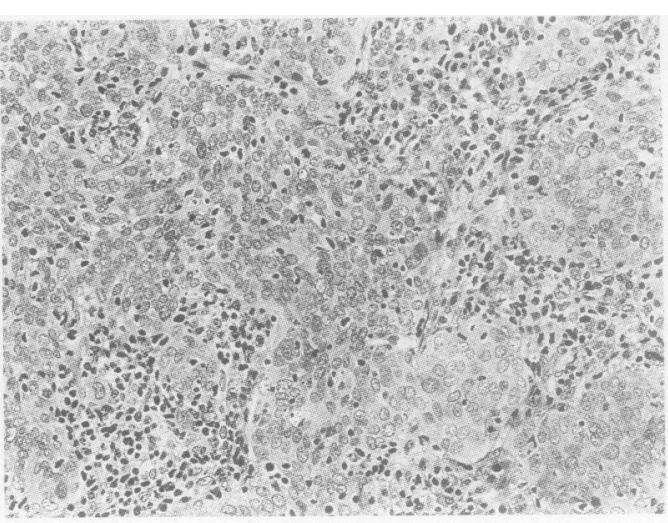

(A)

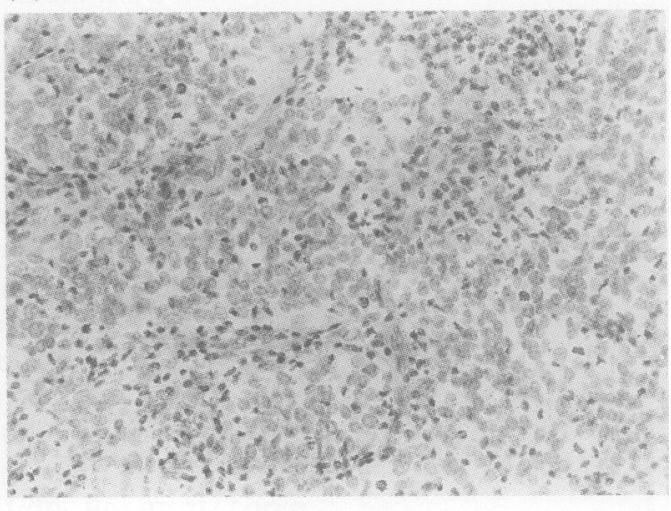

(B)

Figure 2 (A) Lymphoepithelioma-like carcinoma of the cervix (case 4). Syncytial sheets of poorly differentiated malignant cells associated with dense lymphoid infiltrate which percolate the epithelial islands are evident.

(Haematoxylin and eosin, original magnification $\times 198$.)

(B) In situ hybridisation using a ${ }^{35} S$ labelled EBER

probe. The malignant cells were EBV RNA negative

(original magnification $\times 198$ ).

ine cervix was also EBV negative (fig 2B). There were scattered $\kappa$ or $\lambda$ light chain positive plasma cells, confirming the integrity of the RNA in this case.

\section{EBV VIRAL ONCOPROTEIN EXPRESSION}

All cases of salivary gland lymphoepithelial carcinoma expressed LMP-1 in the malignant epithelial cells with both membranous and granular cytoplasmic staining patterns. There was variable staining intensity in different malignant cells within a given tumour and the number of tumour cells which were positive for LMP-1 ranged from $50 \%$ to nearly $100 \%$ in different tumours (figs 4 and 5).

\section{SOUTHERN BLOT HYBRIDISATION}

A single band of, respectively, 12.5 and 9.4 kilobases was detected in cases 7 and 8 , indicating that the virus was present in clonal episomal form in the malignant epithelial cells (fig 6). Smaller fragments, indicative of multiclonality or the linear form of the virus (as seen in the B95-8 cell line), were not detected.

\section{Discussion}

In common with Greenland Eskimos all lymphoepithelial carcinomas of the salivary gland from Hong Kong Chinese examined so far were EBV 


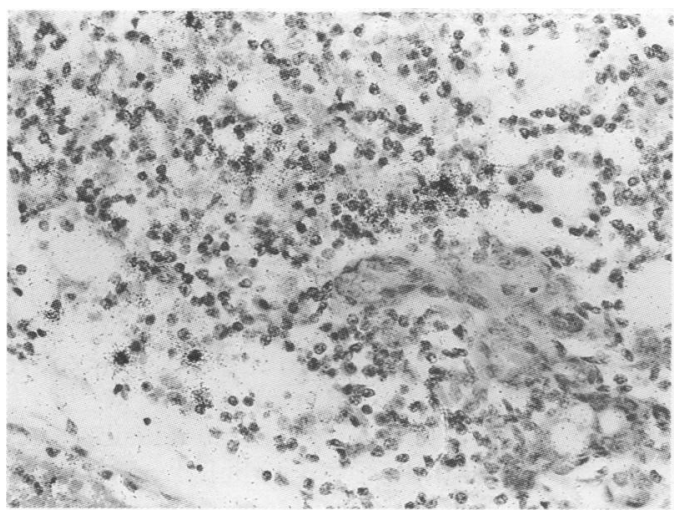

Figure 3 In situ hybridisation using a ${ }^{35} S$ labelled EBER probe (case 1). Scattered lymphocytes showing positive signals are present. The non-neoplastic salivary duct and acini are negative (original magnification $\times 300$ ).

positive. Eskimos have high incidence of both nasopharyngeal carcinoma (12.7 for men and $9 \cdot 2$ for women) and anaplastic carcinoma of the salivary gland ( 3.4 for men and 3.1 for women), ${ }^{16}$ both of which are linked to infection with EBV. In Hong Kong Chinese there is a high incidence of nasopharyngeal carcinoma (28.5/100 000 men and $11 \cdot 2 / 100000$ women) and yet the incidence of malignant neoplasm of the salivary gland is low $(0.7$ for men and 0.5 for women).$^{23}$ Moreover, lymphoepithelial carcinoma constitutes only a minority of the salivary gland malignant neoplasms in our population. In contrast, whites have a low incidence of both tumours and the few salivary gland lymphoepithelial carcinomas from white patients studied so far were all EBV negative. ${ }^{620}$ These findings suggest that there is a complex interaction between genetic factors, environmental factors and the susceptibility of epithelial cells of individual organs to the virus in the oncogenic process.

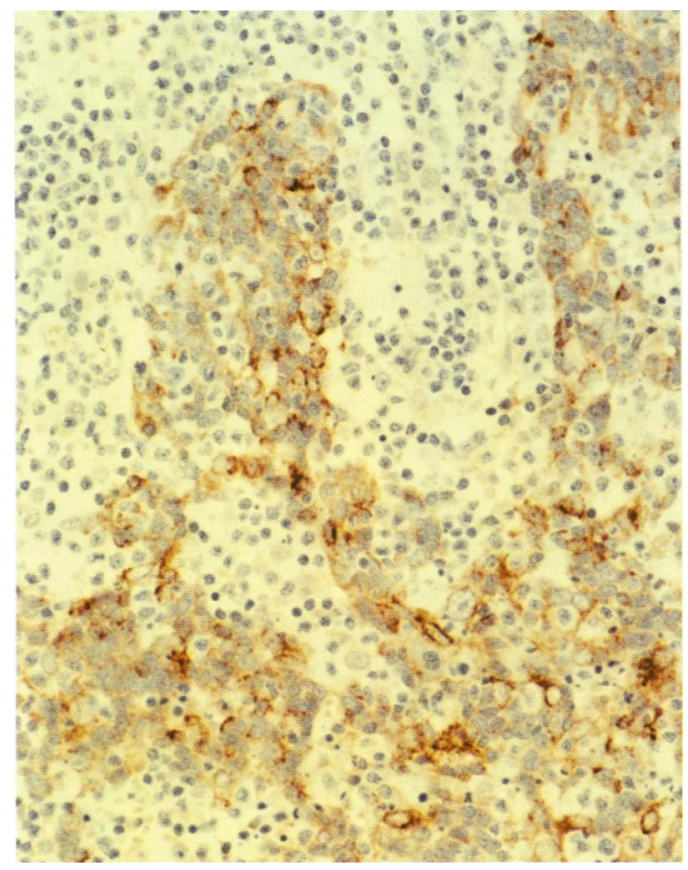

Figure 4 Heterogeneous intensity of staining for LMP-1 in the malignant epithelial cells is evident. Around $60 \%$ of the tumour cells are positive for LMP-1, with both membranous and cytoplasmic staining (case 6$)(\times 240)$.

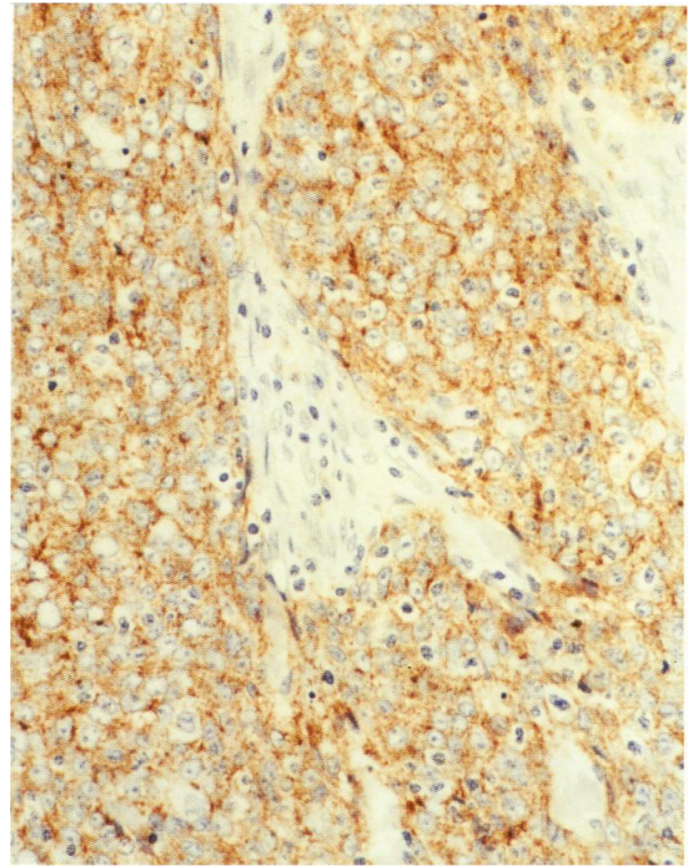

Figure 5 All tumour cells are homogeneously positive for LMP-1 (case 10) $(\times 240)$.

After primary infection, EBV can remain latent in B lymphocytes ${ }^{24}$ (scattered reactive lymphocytes expressing EBV EBER RNA in a few of the cases presented here). Latent EBV is polyclonal and is present in the B lymphocytes in episomal form. As there are far more EBV positive malignant cells compared with lymphocytes, the virus in the lymphocytes may not have been picked up on clonal analysis. EBV is present in the clonal episomal form in most EBV associated malignant neoplasms, examples of which include Burkitt's lymphoma, Hodgkin's lymphoma and lymphoepitheliomas arising in various organs. ${ }^{912526}$ Our results are consistent with those of previous studies. ${ }^{521}$ This suggests that infection with EBV precedes the oncogenic process, and that the virus may play a role in malignant progression. EBV can immortalise B lymphocytes through a complex process requiring several viral proteins including EBV nuclear antigens (EBNAs) and LMPs. EBNA-2 is important in the transformation of B lymphocytes ${ }^{24}$ and LMP-1 has been reported to have transforming properties in rodent fibroblastoid cell lines. ${ }^{27}$ Expression of LMP-1 in B lymphocytes up-regulates $b c l-2$ expression, thus preventing apoptosis. ${ }^{28}$ In human keratinocytes LMP-1 deregulates epithelial growth and inhibits differentiation, ${ }^{2930}$ with the epithelial cells showing the characteristics of transformation including loss of contact inhibition, spindling, a tendency to proliferate into multilayer clusters, and decreased cytokeratin expression. Moreover, there is an impaired cellular response to differentiation signals. Thus, a role for LMP-1 in a multistep pathogenetic process of lymphoepithelioma formation may be inferred from the undifferentiated morphology of the tumour.

Previous immunohistochemical studies in nasopharyngeal carcinomas found that LMP1 was expressed in 22 to $78 \%$ of cases. ${ }^{3132}$ 
Figure 6 Southern blot analysis. All DNA samples were digested with $\mathrm{Bam} H 1$ restriction endonuclease, separated on a $0 \cdot 8 \%$ agarose gel, and hybridised with XhoI EBV fragment. $C=$ control (B95-8 cell line); $8=$ case 8 yielding a single $9 \cdot 4$ kilobase $(\mathrm{kb})$ band; $7=$ case 7 yielding $a$ single $12 \cdot 5 \mathrm{~kb}$ band. These single bands indicate that the clonal episomal form of the virus is present.

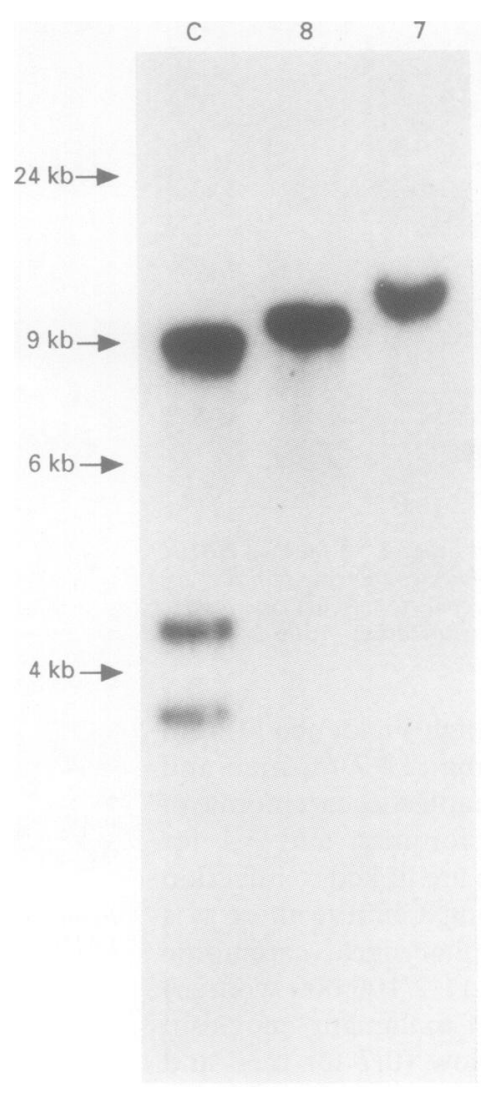

LMP-1 was also expressed in more than $90 \%$ of cases of EBV associated Hodgkin's disease ${ }^{33}$ and in a small percentage of EBV associated sinonasal carcinomas, ${ }^{34}$ but not in Burkitt's lymphoma. ${ }^{35}$ Few data are available concerning the expression of LMP-1 in other EBV associated carcinomas. In the present series LMP-1 was expressed in all 10 lymphoepithelial carcinomas of the salivary gland, with a heterogeneous level of expression in some cases. Heterogeneous LMP-1 expression was also observed in a lymphoblastoid cell line, ${ }^{3637}$ expression of which could be induced by TPA (12-O-tetradecanoyl-phorbol-13-acetate) and butyrate or by the addition of fetal calf serum. However, why the expression is more constant in lymphoepithelial carcinomas of the salivary gland but not in nasopharyngeal carcinoma is not known. It is possible that there is enhanced expression of the protein in the local environment of the salivary gland, which may be important for maintaining the growth and phenotype of the tumour.

It is interesting that two of our three female patients also developed carcinoma of uterine cervix. The cervical carcinoma of one of the patients (case 4) showed lymphoepitheliomalike carcinoma features, including a poorly differentiated morphology with only rare glandular formation and a dense lymphoid infiltrate in the stroma. The simultaneous presence of two tumours of lymphoepithelioma type in the same patient, one EBV positive and the other EBV negative, is intriguing. Although cervical epithelium has been demonstrated as one of the potential sites of EBV infection, ${ }^{38}$ and lymphoepithelioma-like carcinoma has been reported in the cervix, the latter has not been shown to harbour EBV. ${ }^{39}$ It is unfortunate that the cervical carcinoma in case 9 was not available for study, and we do not know whether the morphology was similar to that of case 4 . Taking into account the rarity of lymphoepithelial carcinoma of the salivary gland in our population, the association between it and carcinoma of the uterine cervix in two of the cases in our series is unusual and may suggest the existence of additional unknown factor(s) in the aetiology of lymphoepithelioma-like carcinoma.

In conclusion, we have shown that lymphoepithelial carcinomas of the salivary gland in Hong Kong Chinese uniformly harbour latent EBV. The presence of the virus in clonal episomal form and the expression of LMP-1 in the infected malignant epithelial cells further underlines the importance of EBV in the oncogenetic process.

We thank Dr Elaine Gwi, Pathology Institute, Kwong Wah Hospital, Hong Kong, for providing the pathological specimen from case 5. We also thank Dr R J Collins, Department of Pathology, Queen Mary Hospital, Hong Kong, for reading the manuscript.

1 Niedobitek G, Hansmann ML, Herbst H, Young LS, Dienemann D, Hartmann CA, et al. Epstein-Barr virus and carcinoma: undifferentiated carcinomas but not squamous cell carcinomas of the nasopharyn $x$ are regularly associated with the virus. $\mathcal{F}$ Pathol 1991;165:17-24

2 zur Hausen H, Schulte-Holthausen HS, Klein G, Henle W, Henle G, Clifford P, et al. Epstein-Barr virus DNA in biopsies of Burkitt's tumours and anaplastic carcinoma of the nasopharynx. Nature 1970;228:1056-8.

3 Klein G. The relationship of the virus to nasopharyngeal carcinoma. In: Epstein MA, Achong BG, eds. The EpsteinBarr virus. Berlin: Springer Verlag, 1979:339-50.

4 Dickens P, Srivastava G, Loke SL, Chan CW, Liu YT Epstein-Barr virus DNA in nasopharyngeal carcinomas from Chinese patients in Hong Kong. F Clin Pathol 1992; 45:396-7.

5 Raab-Traub N, Rajadurai P, Flynn K, Lanier AP. EpsteinBarr virus infection in carcinoma of the salivary gland. $f$ Virol 1991;65:7032-6.

6 Hamilton-Dutoit SJ, Therkildsen MH, Neilsen NH, Jensen $\mathrm{H}$, Hansen JP, Pallesen G. Undifferentiated carcinoma of the salivary gland in Greenlandic Eskimos: demonstration of Epstein-Barr virus DNA by in situ nucleic acid hybridization. Hum Pathol 1991;22:811-15.

7 Huang DP, Ng HK, Ho YH, Chan KM. Epstein-Barr virus (EBV) associated undifferentiated carcinoma of the virus (EBV) associated undifferentiated carcinom
parotid gland. Histopathology 1988;13:509-17.

8 Butler AE, Colby TV, Weiss LM, Lombard C. Lymphoepithelioma-like carcinoma of the lung. Am $\mathcal{F}$ Surg Pathol 1989;13:632-9.

9 Pittaluga S, Wong MP, Chung LP, Loke SL. Clonal EpsteinBarr virus in lymphoepithelioma-like carcinoma of the lung. Am f Surg Pathol 1993;1 1:678-82.

10 Leyvraz S, Henle W, Chahinian AP, Perlmann C, Klein G Gordon RE, et al. Association of Epstein-Barr virus with thymic carcinoma. N Engl f Med 1985;312:1296-9.

11 Min KW, Holmquist S, Peiper SC, O'Leary TJ. Poorly differentiated adenocarcinoma with lymphoid stroma (lymphoepithelioma-like carcinomas) of the stomach. $\mathrm{Am}$ f Clin Pathol 1991;96:219-27.

12 Shibata D, Tokunaga M, Uemura Y, Sato E, Tanaka S, Weiss LM. Association of Epstein-Barr virus with undifferentiated gastric carcinoma with intense lymphoid differentiated gastric carcinoma with intense lymphoid
infiltrate-lymphoepithelioma-like carcinoma. Am f Pathol infiltrate - lymphoep
1991;139:469-74.

13 Shibata D, Weiss LM. Epstein-Barr virus-associated gastric adenocarcinoma. Am $\mathcal{F}$ Pathol 1992;140:769-74

14 Yuen ST, Chung LP, Leung SY, Luk ISC, Chan SY, Ho J. In-situ detection of Epstein-Barr virus in gastric and colorectal adenocarcinoma. Am f Surg Pathol 1994;18: 1158-1163.

15 Albeck H, Bentzen J, Ockelmann HH, Nielsen NH, Bretlau $\mathrm{P}$, Hansen HS. Familial clusters of nasopharyngeal carcinoma and salivary gland carcinomas in Greenland natives. Cancer 1993;72:196-200.

16 Albeck H, Nielsen NH, Hansen HE, Bentzen J, Ockelmann $\mathrm{HH}$, Bretlau P, et al. Epidemiology of nasopharyngeal and salivary gland carcinoma in Greenland. Artic Med Res salivary gland carci

17 Merrick Y, Alberk H, Nielsen NH, Hansen HS. Familial clustering of salivary gland carcinoma in Greenland. Canclustering of salivary g
cer 1986;57:2097-102

18 Nielsen NH, Miikkelsen F, Hansen JPH. Incidence of salivary gland neoplasms in Greenland with special reference to anaplastic carcinomas. Acta Pathol Microbiol Scand to anaplastic ca

19 Saw D, Lau WH, Ho JHC, Chan JKC, Ng CS. Malignant lympho-epithelial lesion of the salivary gland. Hum Pathol 1986;17:914-23. 
20 Eversole LR, Gnepp DR, Eversole GM. Undifferentiated carcinoma. In: Ellis GL, Auclair PL, Gnepp DR, eds. Surgical pathology of the salivary gland. Philadelphia: WB Saunders, 1991:422-40.

21 Raab-Traub N, Flynn K. The structure of the termini of the Epstein-Barr virus as a marker of clonal cellular the Epstein-Barr virus as a mark

22 American Joint Committee on Cancer. In: Beahrs $\mathrm{OH}$ Henson DE, Hutter RVP, Myers MH, eds. Manual for Henson DE, Hutter RVP, Myers MH, eds. Manual for staging of cancer. 3 .

23 Poon YF, Poon KM, Au KH. Hong Kong. In: Parkin DM, Muir CS, Whelan SL, Gao YT, Ferlay J, Powell J, eds. Cancer incidence in five continents. Vol VI. Lyon: IARC, 1992:444-7.

24 Kieff E, Liebowitz D. Epstein-Barr virus and its replication. In: Fields BN, Knipe DM, et al, eds. Fundamental virology. 2nd edn. New York: Raven Press, 1991:897-928.

25 Gutierrez MI, Bhatia K, Magrath I. Replicative viral DNA in EBV-associated Burkitt's lymphoma biopsies. Leukemia Res 1993;17:285-9.

26 Weiss LM, Movahed LA, Warnke RA, Sklar J. Detection of Epstein-Barr viral genomes in Reed-Sternberg cells of of Epstein-Barr viral genomes in Reed-Sternberg cell

27 Wang D, Liebovitz AD, Kieff E. An Epstein-Barr virus membrane antigen expressed in immortalized lymphocytes transforms established rodent cells. Cell 1985;43:831-40.

28 Henderson S, Rowe M, Gregory C, Croom-Carter D, Wang $\mathrm{F}$, Longnecker $\mathrm{R}$, et al. Induction of bcl-2 expression by Epstein-Barr virus latent membrane protein 1 protects infected B cells from programmed cell death. Cell 1991; 65:1107-15.

29 Dawson CW, Rickinson AB, Young LS. Epstein-Barr virus latent membrane protein inhibits human epithelial cell latent membrane protein inhibits hum

30 Fahraeus R, Rymo L, Rhim JS, Klein G. Morphological transformation of human keratinocytes expressing the LMP gene of Epstein-Barr virus. Nature 1990;345:447-9.
31 Niedobitek G, Young LS, Sam CK, Brooks L, Prasad U, Rickinson AB. Expression of Epstein-Barr virus genes an of lymphocyte activation molecules in undifferentiated nasopharyngeal carcinomas. Am F Pathol 1992;140:87987.

32 Stewart JP, Arrand JR. Expression of the Epstein-Barr virus latent membrane protein in nasopharyngeal carcinoma biops specimens. Hum Pathol 1993;24:239-42.

33 Delsol G, Brousset P, Chittal S, Francoise R. Correlation of the expression of Epstein-Barr virus latent membrane protein and in situ hybridization with biotinylated BamHIprotein and in situ hybridization with biotinylated BamHI247-53.

34 Leung SY, Yuen ST, Chung LP, Kwong WK, Wong MP, Chan SY. Epstein-Barr virus is present in a wide histological spectrum of sinonasal carcinomas. Am f Surg Pathol (in press).

35 Rowe M, Rowe DT, Gregory CD, Young LS, Farrell PJ, Rupani H, et al. Differences in B cell growth phenotype reflect novel patterns of Epstein-Barr virus latent gene expression in Burkitt's lymphoma cells. EMBO 7 1987;6: 2743-51.

36 Boos $\mathrm{H}$, Stoehr M, Sauter M, Mueller-Lantzsch N. Flow cytometric analysis of Epstein-Barr virus (EBV) latent cytometric analysis of Epstein-Barr virus (EBV latent membrane protein expression

37 Rowe M, Evans HS, Young LS, Hennessy K, Kieff E, Rickinson AB. Monoclonal antibodies to the latent membrane protein of Epstein-Barr virus reveal heterogeneity of the protein and inducible expression in virus-transformed cells. $\mathcal{f}$ Gen Virol 1987;68:1575-86.

38 Sixbey JW, Lemon SM, Pagano JS. A second site for Epstein-Barr virus shedding: the uterine cervix. Lancet 1986;ii:1122-1124.

39 Weinberg E, Hoisington S, Eastman AY, Rice DK, Malfetano J Ross JS. Uterine cervical lymphoepithelial-like carcing $\mathrm{Am}$ carcinoma. Absence of Eathol 1993;99:195-199. 